\title{
INOVASI PEMBELAJARAN PENDIDIKAN AGAMA HINDU PADA SEKOLAH LUAR BIASA (SLB/C) DI TABANAN MENGHADAPI ERA REVOLUSI INDUSTRI 4.0
}

\author{
Oleh: \\ I Ketut Winantra \\ ketutwinantra@unhi.ac.id \\ I Nengah Artawan \\ artawan@unhi.ac.id \\ Universitas Hindu Indonesia Denpasar
}

\begin{abstract}
ABSTRAK
Di era Revolusi Industri 4.0., proses belajar-mengajar Pendidikan Agama Hindu harus mengalami inovasi dan pengembangan metode pembelajaran. Tujuannya adalah memberikan siswa kemudaan dalam memahami berbagai materi dalam lingkup praktik-praktik keagamaan Hindu yang sesuai dengan tuntutan teknologi informasi, terutama bagi siswa Sekolah Luar Biasa (SLB/C) bagi para Tuna Grahita dalam pembelajaran jarak jauh atau daring. Inovasi dalam pengembangan metode pembelajaran pendidikan Agama Hindu di SLB/C ini bertujuan agar sesuai dengan IQ yang dimiliki masing-masing siswa yang sudah didasarkan pada ketentuan yang ada. Pembelajaran Pendidikan Agama Hindu dibagi menjadi tiga jenis yaitu: pembelajaran kelas, praktik pendidikan, serta pendidikan luar kelas. Hal ini tidaklah mudah, karena untuk SLB $/ \mathrm{C}$ membutuhkan penanganan yang luar biasa terutama para dewan guru harus memiliki tingkat kesabaran yang tinggi. Berdasarkan hasil penelitian, inovasi dan pengembangan metode pembelajaran dilaksanakan melalui media informasi berupa rekaman audio dan visual dengan komputer, laptop atau android. Hali ini memudahkan para guru dan orang tua siswa dalam memberikan materi pembelajaran, sehingga terjadi perbaikan dalam metode pembelajaran pendidikan Agama Hindu pada Sekolah Luar Biasa (SLB/C) yang khusus untuk Tuna Grahita.
\end{abstract}

Kata Kunci: Inovasi, Metode Pembelajaran, Pendidikan Agama, SLB/C

\section{ABSTRACT}

In the era of the Industrial Revolution 4.0., the teaching and learning process of Hindu Religious Education must experience innovation and development of learning methods. The aim is giving students in understanding various materials within the scope of Hindu religious practices in accordance with the demands of information technology, especially for the students of special schools $(S L B / C)$ for Tuna Grahita in distance learning or online. This innovation in the development of learning methods for Hindu Religion education in special schools is intended to match the IQ of each student which is already based on existing provisions. The Hindu Religious 
Education learning is divided into three types, namely: classroom learning, educational practice, and education outside the classroom. This is not easy, because $S L B$ / C requires extraordinary handling, especially the teacher councils must have a high level of patience. Based on the results of research, innovation and development of learning methods are carried out through information media in the form of audio and visual recordings with a computer, laptop or android. This makes it easier for the teachers and the parents of the students to provide learning materials, so that there is an improvement in the learning methods of Hindu Religion education at Special Schools $(S L B / C)$ which are specifically for Tuna Grahita.

Keywords: Innovation, Learning Methods, Religious Education, SLB/C

\section{PENDAHULUAN}

SLB merupakan sekolah yang khusus menangani anak-anak yang mempunyai karakter/ciri berbeda dibanding anak-anak pada umunya (bukan tidak sempurna). Oleh sebab itulah, peranan media akan sangat dibutuhkan untuk menunjang kegiatan dan pencapaian hasil belajar, khususnya bagi para pelajar di SLB. Para guru di SLB seharusnya tidak hanya pandai memahami masalah ini, tetapi juga menerapkan prinsip kreatif tersebut. Mayoritas para guru beralasan, minimnya penguasaan teknologi berbasis komputer menjadi kendala utamanya. Padahal, tanpa computer, media pembelajaran juga dapat diciptakan dan dimanfaatkan. Misalnya, pada anak SLB/C (untuk anak Tuna Grahita), tentu saja untuk mengajarkan suatu materi pada siswa SDLB/C akan terlihat lebih sulit dibandingkan dengan siswa SD umumnya, karena anak kategori ini mempunyai tingkat kecerdasan relatif lebih rendah.

Di samping itu, pendidikan berorientasi revolusi 4.0 menekankan pada pengembangan atau perubahan ke arah teknologi informasi. Saat ini di SLB/C yang ada di Kabupaten Tabanan masih menggunakan metode pembelajaran model lama yang ada yaitu menekankan pada pengulangan materi sehingga untuk siswa dengan IQ yang berbed a akan menjadi hal yang kurang menarik. Dari beberapa kondisi tersebut maka peneliti ingin melakukan inovasi pengembangan metode pembelajaran Pendidikan Agama Hindu di sekolah Luar Biasa (SLB/C) yang ada di Kabupaten Tabanan.Sehingga terjadi pembelajaran yang menyenangkan untuk mata pelajaran Pendidikan Agama Hindu.

\section{METODE PENELITIAN}

Studi ini merupakan penelitian kualitatif dengan metode deskriptif kualitatif. Data primer diperoleh menggunakan teknik observasi partisipasi, wawancara mendalam dengan para informan yang telah ditentukan secara purposif. Metode awal berupa observasi dilakukan secara bertahap sehingga didapatkan bagaimana melakukan perancangan inovasi dalam pembelajaran khususnya pendidikan Agama Hindu pada Sekolah Luar Biasa (SLB/C) yang ada di Kabupaten Tabanan. Selanjutnya kajian pustaka dilakukan terhadap hasil penelitian yang telah lalu yang dilakukan di SLB/C Kemala Bhayangkari, untuk membandingkan dan melihat model pembelajaran mungkin diterapkan.

\section{PEMBAHASAN}

Menurut Gagne dan Briggs, pembelajaran adalah suatu sistem yang bertujuan untuk membantu proses belajar peserta didik yang berisi serangkaian 
peristiwa yang didesain untuk mempengaruhi dan mendukung terjadinya proses belajar peserta didik yang bersifat internal. Berdasarkan uraian tersebut, pada pembelajaran diperlukan strategi yang tepat agar tujuan pembelajaran dapat tercapai.Strategi adalah ilmu siasat perang atau bahasa pembicaraan akal untuk mencapai suatu maksud atau tujuan tertentu (Moeliono, 1988:859).

Pada awal Tahun 2020, dimana mulainya masa pembelajaran Semester II (kedua) Tahun ajaran 2019/2020. Dari pengamatan dan wawancara dengan beberapa narasumber terkait dengan Pembelajaran Pendidikan Agama Hindu Pada Sekolah Luar Biasa (SLB/C) yang ada di Tabanan, yaitu SLB Negeri 1 Tabanan, untuk Tuna Grahita, dan SLB/C Kemala Bhayangkari, yang berlokasi di Desa Mandung, Kecamatan Kerambitan.

\subsection{Metode pembelajaran Pendidikan Agama Hindu di SLB/C di Kabupaten Tabanan}

Dari hasil observasi awal ditemukan bahwa untuk metode pembelajaran yang dilakukan saat ini di SLB/C sangat jauh berbeda atau lebih sulit dibandingkan dengan SLB yang lainnya. Pada SLB/C para guru dituntut memiliki kesabaran yang tinggi, karena para siswa dengan kemampuan IQ yang dalam kondisi kurang serta autis.Dari pengamatan peneliti pada 2 sekolah luar Biasa di Kabupaten Tabanan, memang terlihat suasana yang jauh dari kondisi siswa normal. Dari hasil wawancara dengan nara sumber yaitu Kepala sekolah pada kedua sekolah tersebut, pengajar pendidikan Agama Hindu, di SLB/C Negeri 1 Tabanan, dan SLB/C Kemala Bhayangkari didapatkan kondisi bahwa tidak diterapkan metode pembelajaran seperti yang dilakukan pada sekolah umum ataupun SLB yang lainnya. Untuk saat ini karena fasilitas penunjang belum maksimal maka metode pembelajaran yang dilakukan hanya sebatas metode Demontrasi, dan metode remidi, tentunya dengan beberapa pendekatanpendekatan persuasif, terhadap anak didik dan orang tua pendamping. Hal yang serupa juga disampaikan para guru ketika melakukan rapat dan penjelasan mengenai penerapan metode pembelajaran yang dilakukan pada SLB Negeri 1 Tabanan, khusus untuk Tuna Grahita (SLB/C).

Secara umum sesuai dengan hasil penelitian sebelumnya yang dilakukan di SLB/C Kemala Bhayangkari tahun 2018 terkait dengan metode pembelajaran Pendidikan Agama Hindu yang diterapkan ada beberapa metode diantaranya :

1) Metode Ceramah (Dharma Wacana) adalah pelaksanaan mengajar dengan ceramah secara oral, lisan, dan tulisan diperkuat dengan menggunakan media visual. Pendidik berperan sebagai sumber pengetahuan utama atau dominan. Belajar agama dengan metode Dharma Wacana dapat memperoleh ilmu agama dengan mendengarkan wejangan dari guru. metodeDharma Wacana termasuk dalam ranah pengetahuan dalam dimensi Kompetensi Inti.

2) Metode Dharmagītā adalah metode mengajar dengan pola menyanyi atau melantunkan sloka, palawakya, dan tembang. Pendidik dalam proses pembelajaran melibatkan rasa seni yang dimiliki setiap peserta didik, terutama seni suara atau menyanyi, sehingga dapat menghaluskan budhi pekertinya dan dapat memahami ajaran Agama.

3) Metode Diskusi (Dharma Tula) adalah metode mengajar dengan cara mengadakan diskusi dikelas. Metode Dharma Tula digunakan untuk memberikan kesempatan kepada peserta didik yang memiliki kecerdasan yang berbeda-beda. Dengan menggunakan metode Dharma Tula peserta didik 
dapat memberikan kontribusi dalam pembelajaran.

4) Metode Karya Wisata (Dharma Yatra) adalah metode pembelajaran dengan cara mengunjungi tempat-tempat suci atau pergi ketempat-tempat yang dianggap terkait perkembangan Agama Hindu. Strategi Dharma Yatra baik digunakan pada saat menjelaskan materi tempat suci, hari suci, budaya dan sejarah perkembangan Agama Hindu.

5) Metode Dharma Shanti adalah metode pembelajaran untuk menanamkan sikap saling asah, saling asih, dan saling asuh yang penuh dengan rasa toleransi. metodeDharma Shanti dalam pembelajaran memberikan kesempatan kepada peserta didik, untuk saling mengenali temannya, sehingga menumbuhkan rasa saling menyayangi.

6) Metode Demontrasi (Dharma Sadhana) adalah strategi pembelajaran untuk menumbuhkan kepekaan sosial peserta didik melalui pemberian atau pertolongan yang tulus ikhlas dan mengembangkan sikap berbagi kepada sesamanya.

\subsection{Inovasi metode Pembelajaran Pendidikan Agama Hindu yang dapat dikembangkan, pada $\mathrm{SLB} / \mathrm{C}$ di Kabupatem Tabanan.}

Dari hasil wawancara dengan Guru Pendidikan Agama Hindu I pada SLB/C Kemala Bhayangkari Pada tanggal 13 April 2020, Nyoman Wiartana, S.Pd.H dimana untuk para siswa sudah tidak melakukan kegiatan di sekolah. Pembelajaran Pendidikan Agama Hindu tidak hanya menyangkut teori atau pembelajaran di kelas saja tetapi juga mengenai kegiatan praktik pembuatan sarana persembahyangan, dan di luar kelas atau di masyarakat. Pembelajaran pendidikan Agama Hindu pada sekolah Luar Biasa (SLB/C tuna grahita), memang banyak metode pembelajaran yang disarankan uuntuk dilaksanakan namun saat ini yang dimungkinkan untuk dilaksanakan dalam proses pembelajaran pendidikan agama Hindu adalah metode demontrasi dan metode remidi.

\subsubsection{Metode Pembelajaran Pendidikan Agama Hindu Demontrasi}

Metode demonstrasi adalah metode panyajian pelajaran dengan memeragakan dan menunjukkan kepada siswa tetang suatu proses, situasi atau benda tertentu, baik sebenarnya atau hanya sekedar tiruan. Terlepas dari metode penyajian tidak terlepas dari penjelasan guru. Walau dalam metode demonstrasi siswa hanya sekedar memperhatikan.(Ahmad Mujin Nasih dan Lilik Nur Kholidah, 2009)

Menurut Drajat metode demonstrasi merupakan metode yang menggunakan peragaan untuk memperjelas atau pengertian atau untuk memperlihatkan bagaimana melakukan sesuatu kepada peserta lain. Demonstrasi merupakan metode pembelajaran yang efektif, karena peserta didik dapat mengetahui secara langsung penerapan materi tersebut dalam kehidupan sehari-hari.(Miftahul Huda;2013).

Metode pembelajaran demonstrasi adalah cara penyajian pembelajaran dengan meragakan dan mempertunjukkan suatu proses, situasi atau benda tertentu yang sedang dipelajari baik dalam bentuk sebenarnya maupun dalam bentuk tiruan yang yang dipertunjukkan oleh guru atau sumber belajar lain di depan seluruh siswa

Metode Demontrasi (Dharma Sadhana) adalah metode pembelajaran untuk menumbuhkan kepekaan sosial peserta didik melalui pemberian atau pertolongan yang tulus ikhlas dan mengembangkan sikap berbagi kepada sesamanya.

Dengan metode demonstrasi, proses penerimaan siswa terhadap pelajaran akan 
lebih berkesan secara mendalam, sehingga membentuk pengertian dengan baik dan sempurna. Juga siswa dapat mengamati guru selama proses pebelajaran berlangsung. Adapun penggunaan metode demonstrasi mempunyai tujuan agar siswa mampu memahami tentang cara mengatur atau menyusun sesuatu misalnya dalam materi Pendidikan Agama Hindu tata cara dalam melakukan persembahyangan, tata cara melakukan "Tri Sandya", dan sebagainya. Adapun langkah-langkah dalam penggunaan metode demonstrasi antara lain:

a) Mulailah demonstrasi dengan kegiatankegiatan yang metangsang peserta didik untuk berfikir, misalnya melaui pertanyaan-pertayaan yang mengandungb teka teki sehingga mendorong peserta didik untuk tertarik memperhatika demonstrai.

b) Ciptakan suasana yag menyejukkan dengan menghindari suasana yang menegangkan.

c) Yakin bahwa semua peserta didik mengikuti jalannya pembelajaran demonstrasi dengan memperhatikan seluruh reaksi peserta didik.

d) Berikan kesempatan pada peserta didik untuk secara aktif memikirkan lebih lajut sesuai dengan apa yag dilihat dari proses demonstrasi itu.

e) Untuk mengakhiri kegatan pembelajaran dengan metode demonstrasi adalah dengan memberikan beberapa tugas tertentu yang memiki keterkaitan dengan materi yang diberikan.

\subsubsection{Metode Pembelajaran Pendidikan Agama Hindu Remedial}

Ada beberapa pendapat para pakar pendidikan tentang pengertian remedial teaching, sebagai berikut:

1. Ahmadi dan Supriyono mendefiisikan remedial teaching adalah suatu bentuk pengajaran yang bersifat menyembuhkan atau membetulkan dengan singkat pengajaran yang membuat menjadi baik. Program remedial ini diharapkan dapat membantu siswa yang belum tuntas untuk mencapai keuntasan hasil belajarnya. Pengajaran remedial juga bisa dikatakan sebagai pengajaran terapis atau penyembuhan artinya yang disembuhkan dalam pengajaran ini adalah beberapa hambatan atau gangguan kepribadian yang berkaitan dengan kesulitan belajar.

2. Iscak dan Warji memberikan pengertian remedial teaching yaitu kegiatan perbaikan dalam proses belajar mengajar atau salah satu bentuk bantuan, yaiu dalam bentuk proses belajar mengajar adalah salah satu bentuk pemberian bantuan. Pemberian bantuan dalam proses belajar mengajar yang berupa kegiatan perbaikan terprogram dan disusun secara sistematis.

3. Menurut M. Entang, pengertian remedial teaching adalah segala usaha yang dilakukan untuk memahami dan menetapkan jenis sifat kesulitan belajar. Faktor-faktor penyebabnya serta cara menetapkan kemungkinan mengatasinya. Baik secara kuratif (penyembuhan) maupun secara preventif (pencegahan) berdasarkan data dan informasi yang seobyektif mungkin.

4. Menurut Addurrahman menyatakan bahwa remedial teaching pada hakikatnya merupakan kewajiban bagi semua guru setelah mereka melakukan evaluasi formatif dan menemukan adanya peserta didik yang belum mencapai tujuan belajar yang ditetapkan.

Dari beberapa pendapat diatas dapat disimpulkan bahwa pengertian remedial teaching adalah sebagai suatu bentuk 
pengajaran khusus, yang ditujukan untuk menyembuhkan atau memperbaiki sebagian atau seluruh kesulitan belajar yang dihadapi oleh siswa. Adapun ciri-ciri remedial teaching jika dibandingkan dengan pengajaran biasa adalah sebagai berikut:

1. Dilakukan setelah diketahui kesulitan belajar dan kemudian diberikan pelayanan khusus sesuai dengan jenis, sifat, dan latar belakang.

2. Diberikan sesuai dengan kesulitan belajar yang dihadapi siswa.

3. Metode yang digunakan bersifat deferensial disesuaikan dengan sifat jenis dan latar belakan kesulitan belajar.

Penerapan metode ini sudah dilakukan dalam pembelajaran pendidikan agama hindu pada SLB/C Kemala Bhayangkari pada semester genap tahun ajaran 2019-2020. Beberapa prinsip yang perlu diperhatikan dalam pembelajaran remedial sesuai dengan sifatnya sebagai pelayanan khusus antara lain:

a. Adaptif. Pembelajaran remedial hendaknya memungkinkan siswa untuk belajar sesuai dengan daya tangkap, kesempatan, dan gaya belajar masingmasing.

b. Interaktif. Pembelajaran remedial hendaknya melibatkan keaktifan guru untuk secara intensif berinteraksi dengan siswa dan selalu memberikan monitoring dan pengawasan agar mengetahui kemajuan belajar siswanya.

c. Fleksibilitas dalam metode pembelajaran dan penilaian. Pembelajaran remedial perlu menggunakan berbagai metode pembelajaran dan metode penilaian yang sesuai dengan karakteristik siswa.

d. Pemberian umpan balik sesegera mungkin. Umpan balik berupa informasi yang diberikan kepada siswa mengenai kemajuan belajarnya perlu diberikan sesegera mungkin agar dapat menghindari kekeliruan belajar yang berlarut-larut.

e. Pelayanan sepanjang waktu. Pembelajaran remedial harus berkesinambungan dan programnya selalu tersedia agar setiap saat siswa dapat mengaksesnya sesuai dengan kesempatan masing-masing.

Kedua metode pembelajaran yang sudah diterapkan pada sebelum masa Covid 19 pada awal tahu 2020, tidak dapat diterapkan saat ini, sehingga perlu adanya modifikasi model pembelajaran dengan system "Daring" (Dalam Jaringan), atau dengan sisitem online. Sehingga dari beberapa jenis kegiatan yang dilakukan di sekolah untuk metode pembelajaran dilakukan pengembangan dengan penerapan alat bantu system informasi audio visual, yang ditujukan kepada orang tua siswa, sehingga dilakukan 2 sistem daring atau dapat diistilahkan "Double Daring".

\subsection{Metode \\ Pengembangan \\ Pembelajaran Pendidikan Agama Hindu Berorientasi Revolusi Industri 4.0.}

Era revolusi industri 4.0 merupakan tantangan berat bagi guru Indonesia. Mengutip pandangan dari Jack Ma dalam pertemuan tahunan World Economic Forum 2018, pendidikan adalah tantangan besar abad ini. Jika tidak mengubah cara mendidik dan belajar-mengajar, 30 tahun mendatang kita akan mengalami kesulitan besar. Pendidikan dan pembelajaran yang sarat dengan muatan pengetahuan mengesampingkan muatan sikap dan keterampilan sebagaimana saat ini terimplementasi, akan menghasilkan peserta didik yang tidak mampu berkompetisi dengan mesin. Dominasi pengetahuan dalam pendidikan dan pembelajaran harus diubah agar kelak anak-anak muda Indonesia mampu mengungguli kecerdasan mesin 
sekaligus mampu bersikap bijak dalam menggunakan mesin untuk kemaslahatan.

Siapkah guru di Indonesia menghadapi era revolusi industri 4.0 ketika masih disibukkan oleh beban penyampaian muatan pengetahuan dan ditambah berbagai tugas administratif? Saat ini guru merasa terbebani dengan kurikulum dan beban administratif yang terlalu padat sehingga tidak lagi memiliki waktu tersisa memberi peluang anak didik menjelajahi daya-daya kreatif mereka menghasilkan karya-karya orisinal.Akibatnya, interaksi sosial anak didik terbatasi, daya kreasinya terbelenggu, dan daya tumbuh budi pekerti luhurnya bantet.

Era revolusi industri 4.0 akan berdampak pada peran pendidikan khususnya peran pendidiknya. Jika peran pendidik masih mempertahankan sebagai penyampai pengetahuan, maka mereka akan kehilangan peran seiring dengan perkembangan teknologi dan perubahan metode pembelajarannya. Kondisi tersebut harus diatasi dengan menambah kompetensi pendidik yang mendukung pengetahuan untuk eksplorasi dan penciptaan melalui pembelajaran mandiri.

Dunia pendidikan pada era revolusi industry berada di masa pengetahuan (knowledge age) dengan percepatan peningkatan pengetahuan yang luar biasa.Percepatan peningkatan pengetahuan ini didukung oleh penerapan media dan teknologi digital yang disebut dengan information super highway (Gates, 1996).Gaya kegiatan pembelajaran pada masa pengetahuan (knowledge age) harus disesuaikan dengan kebutuhan pada masa pengetahuan (knowledge age).Bahan pembelajaran harus memberikan desain yang lebih otentik untuk melalui tantangan di mana peserta didik dapat berkolaborasi menciptakan solusi memecahkan masalah pelajaran. Pemecahan masalah mengarah ke pertanyaan dan mencari jawaban oleh peserta didik yang kemudian dapat dicari pemecahan permasalahan dalam konteks pembelajaran menggunakan sumber daya informasi yang tersedia Trilling and Hood, 1999 : 21).

Tuntutan perubahan mindset manusia abad 21 yang telah disebutkan di atas menuntut pula suatu perubahan yang sangat besar dalam pendidikan nasional, yang kita ketahui pendidikan kita adalah warisan dari sistem pendidikan lama yang isinya menghafal fakta tanpa makna. Merubah sistem pendidikan indonesia bukanlah pekerjaan yang mudah. Sistem pendidikan Indonesia merupakan salah satu sistem pendidikan terbesar di dunia yang meliputi sekitar 30 juta peserta didik, 200 ribu lembaga pendidikan, dan 4 juta tenaga pendidik, tersebar dalam area yang hampir seluas benua Eropa. Namun perubahan ini merupakan sebuah keharusan jika kita tidak ingin terlindas oleh perubahan zaman global.

P21 (Partnership for 21st Century Learning) mengembangkan framework pembelajaran di abad 21 yang menuntut peserta didik untuk memiliki keterampilan, pengetahuan dan kemampuan dibidang teknologi, media dan informasi, keterampilan pembelajaran dan inovasi serta keterampilan hidup dan karir (P21, 2015). Framework ini juga menjelaskan tentang keterampilan, pengetahuan dan keahlian yang harus dikuasai agar siswa dapat sukses dalam kehidupan dan pekerjaannya.

Sejalan dengan hal itu, Kemendikbud merumuskan bahwa paradigma pembelajaran abad 21 menekankan pada kemampuan peserta didik dalam mencari tahu dari berbagai sumber, merumuskan permasalahan, berpikir analitis dan kerjasama serta berkolaborasi dalam menyelesaikan masalah (Litbang Kemdikbud, 2013). Adapun penjelasan mengenai framework pembelajaran abad ke21 menurut (BSNP:2010) adalah sebagai berikut: (a) Kemampuan berpikir kritis dan 
pemecahan masalah (Critical-Thinking and Problem-Solving Skills), mampu berfikir secara kritis, lateral, dan sistemik, terutama dalam konteks pemecahan masalah; (b) Kemampuan berkomunikasi dan bekerjasama (Communication and Collaboration Skills), mampu berkomunikasi dan berkolaborasi secara efektif dengan berbagai pihak;(c) Kemampuan mencipta dan membaharui (Creativity and Innovation Skills), mampu mengembangkan kreativitas yang dimilikinya untuk menghasilkan berbagai terobosan yang inovatif; (d) Literasi teknologi informasi dan komunikasi (Information and Communications Technology Literacy), mampu memanfaatkan teknologi informasi dan komunikasi untuk meningkatkan kinerja dan aktivitas sehari-hari; (e) Kemampuan belajar kontekstual (Contextual Learning Skills), mampu menjalani aktivitas pembelajaran mandiri yang kontekstual sebagai bagian dari pengembangan pribadi, dan (f) Kemampuan informasi dan literasi media, mampu memahami dan menggunakan berbagai media komunikasi untuk menyampaikan beragam gagasan dan melaksanakan aktivitas kolaborasi serta interaksi dengan beragam pihak.

Untuk menghadapi pembelajaran di abad 21, setiap orang harus memiliki keterampilan berpikir kritis, pengetahuan dan kemampuan literasi digital, literasi informasi, literasi media dan menguasai teknologi informasi dan komunikasi (Frydenberg \& Andone, 2011).

Keterbatasan waktu dalam penyampaian materi mengakibatkan siswa tunagrahita ringan lebih lama dalam memahami catatan dari guru saat belajar mandiri di rumah, sehingga dibutuhkan suatu media pendukung dalam pembelajaran.Media adalah alat pengantar pesan dari pengirim kepada penerima pesan (Arsyad, 2013). Media yang digunakan untuk memperlancar komunikasi dalam proses pembelajaran sering diistilahkan media pembelajaran. Media pembelajaran adalah segala sesuatu yang dapat digunakan untuk menyampaikan pesan atau informasi dalam proses belajar mengajar sehingga dapat merangsang perhatian dan minat siswa dalam belajar (Arsyad, 2013).

Media audio visual merupakan salah satu media pembelajaran yang diharapkan dapat mengoptimalkan proses pembelajaran karena media audio visual mempunyai keunggulan yaitu siswa belajar menggunakan indra penglihat dan pendengar. Siswa akan belajar lebih banyak dengan indra ganda daripada belajar hanya menggunakan indra pendengar atau indra penglihat saja. Keuntungan lainnya adalah media lebih menarik perhatian siswa, mudah digunakan pada saat proses pembelajaran berlangsung, media audio visual berbasis teknologi sehingga dapat diperbaiki setiap saat. Diharapkan media audio visual dapat membantu siswa tunagrahita ringan untuk memperoleh informasi secara optimal dan lebih mengingat apa yang telah mereka pelajari. Pemerolehan informasi dapat terjadi karena interaksi antara pengalaman baru dan pengalaman yang pernah dialami sebelumnya.Menurut Bruner (1966) dalam Arsyad (2013) ada tiga tingkatan utama modus belajar, yaitu pengalaman langsung (enactive), pengalaman piktorial/ gambar (iconic), dan pengalaman abstrak (symbolic). Pengalaman langsung adalah mengerjakan, pengalaman piktorial berarti mempelajari dari gambar, lukisan, foto, video, atau film, dan pengalaman abstrak/simbol yaitu keadaan dimana siswa mendengar dan mencoba mencocokkan apa yang didengar dengan pengalaman langsung dan pengalaman piktorial sehingga diperoleh pengalaman, pengetahuan, ketrampilan, dan sikap yang baru. Dari ketiga tingkatan modus belajar, pengalaman langsung adalah pengalaman yang paling tepat dalam proses pembelajaran. Namun, pada kenyataanya 
tidak semua bahan pelajaran dapat disajikan secara langsung untuk siswa tunagrahita ringan. Perilaku yang tidak dapat mengatur diri sendiri dan IQ yang rendah merupakan salah satu alasan mengapa siswa tunagrahita ringan akan mudah lupa apabila diberi materi pengalaman langsung yang hanya sekali karena siswa akan cenderung bermain-main. Oleh karena itu, pembelajaran menggunakan media diharapkan dapat membantu jalannya proses pembelajaran dan di rumah pun orang tua dapat membimbing siswa belajar menggunakan media yang sama dengan di sekolah, sehingga materi yang disampaikan dapat melekat pada ingatan karena diajarkan secara berulang-ulang. Selain itu, Levie \& Levie (1975) dalam Arsyad (2013) mengungkapkan bahwa belajar melalui stimulus gambar dan stimulus kata atau visual dan audio membuahkan hasil belajar yang lebih baik untuk tugas-tugas seperti mengenali, mengingat kembali, dan menghubungkan fakta dengan konsep.

Dari pembelajaran Audio Visual berupa pemutaran film / cerita dongeng yang terkait dengan pendidikan agama hindu yang dilaksanakan di SLB $-\mathrm{C}$ Kemala Bhayangkari Tabanan, terlihat seperti dalam gambar berikut.

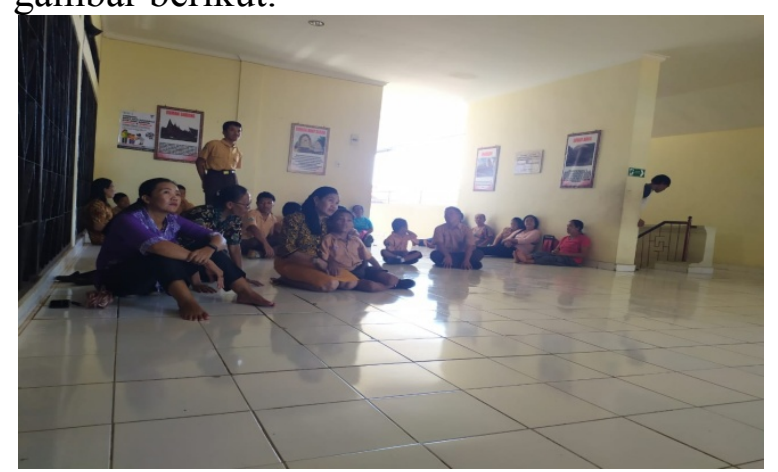

Gambar 3.1. Siswa SLB_C Kemala

Bhayangkari, diberikan Pembelajaran Audia Visual

Dari gambar di atas ketika sekolah masih di buka, sudah dicobakan untuk proses pembelajaran dengan menggunakan media Audio Visual, dengan catatan bahwa para guru juga harus ikut melakukan pengawasan ekstra terhadap para sisiwa, sehingga semua bisa lebih aman. Ide inilah yang yang kemudian dikembangkan dalam sistempembelajaran saat ini untuk sisa SLB - C khusus tuna grahita dilakukan dengan system "Daring " tetapa di tujukan kepada orang tuanya. Pembelajaran siswa SLB/C di rumah masing-masing dilakukan dengan terus ada pemantauan dan pengawasan dari orang tua siswa.

Pengembangan metode Pembelajaran Demontrasi dan Remedial yang diterpakan pada pembelajaran Pendidikan Agama Hindu pada sekolah luar biasa, khusus untuk yang tuna grahita, perlu dikemas dengan sentuhan teknologi informasi, sehingga lebih meyenangkan. Metode demontrasi dilakukan dengan merekan terlebih dahulu apa yang akan diberikan pembelajaran, seperti untuk carita-cerita keagamaan, cara melakukan puja trisandya sesua dengan kemampuan mereka. Setiap kelompok siswa dilakukan perlakukan yang berbeda.Setelah metode demontasi ini di dapatkan barulah bisa dilakukan metode remedial, atau melakukan pemutaran ulah terhadap hasil video / audi cisual yang sudah di buat.

Membutuhkan kerjasama yang baik dengan pihak orang tua terhadap metode pembelajaran yang diterapkan saat ini, karena semua materi yang disampaikan pertama harus dipahami secara mendasar oleh orang tua, dan baru orang tuan menyampaikan kepada siswa. Seperti contoh dalam masa aman sekolah diberikan latihan melalui audio visual dalam gerak tubuh seperti di Bawah ini. 


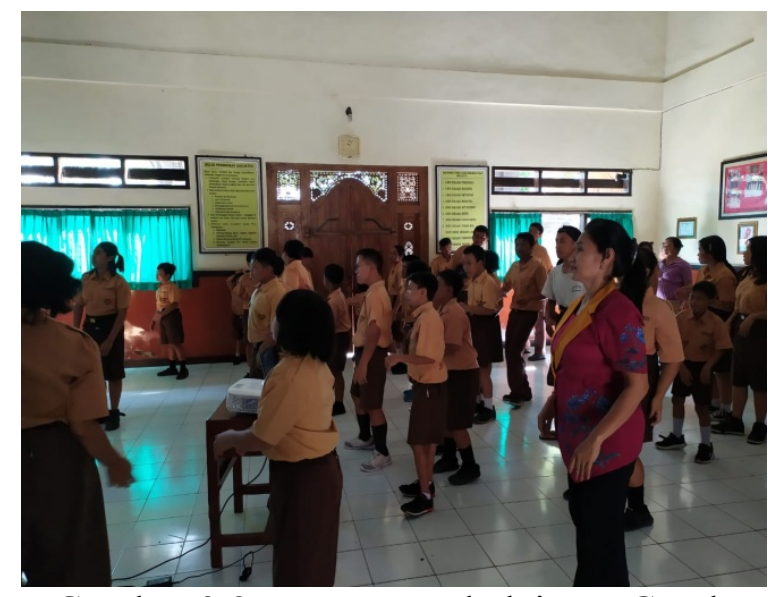

Gambar 3.2. Proses Pembelajaran Gerak melalui Audio Visual

Metode ini diawal memang sangat menyulitkan karena para guru di tuntut untuk membuat bahan ajar berupa video ataupun youtube, yang pada nantinya di pelajari / dipahami dulu oleh orang tua, baru akhirnnnya kepada siswa.

\section{PENUTUP}

Peranan guru pengajar dan pendidik pada Sekolah Luar Biasa (SLB/C) Tuna Grahita, tidaklah sama dengan sekolah umum, membutuhkan kesabaran yang cukup tinggi, karena mereka adalah para siswa dengan berbagagai keterbatasan. Khususnya untuk Guru pendidikan Agama Hindu sangat memegang peranan penting dalam memberikan pendidikan dan pengajaran, selain memberikan ilmu pengetahuan, seorang guru agama juga diharapkan dapat membentuk dan memperkuat karakter dan budi pekerti siswa, tidak hanya di sekolah atau di luar kelas, tetapi juga di rumah atau di masyarakat.

Pengembangan metode Pembelajaran Demontrasi dan Remedial yang diterpakan pada pembelajaran Pendidikan Agama Hindu pada sekolah luar biasa, khusus untuk yang tuna grahita, perlu dikemas dengan sentuhan teknologi informasi, sehingga lebih meyenangkan. Metode demontrasi dilakukan dengan merekan terlebih dahulu apa yang akan diberikan pembelajaran, seperti untuk cerita-cerita keagamaan, cara melakukan puja trisandya sesua dengan kemampuan mereka. Setiap kelompok siswa dilakukan perlakukan yang berbeda.Setelah metode demontasi ini di dapatkan barulah bisa dilakukan metode remedial, atau melakukan pemutaran ulah terhadap hasil video / audi cisual yang sudah di buat.Tentu saja pelaksanaan metode ini tidaklah mudah tanpa adanya dukungan pihak-pihak terkait seperti Dinas Pendidikan dalam penyedia sarana dan prasarana, serta pihak swasta yang memiliki kepedulian dalam pemberian pendidikan kepada anak inklusi khusus tipe C, yang mana untuk di Tabanan, di bawah naungan yayaysan Kemala Bhayangkari. Semoga apa yang dihasilkan dalam penelitian ini dapat bermanfaat dan dapat diterapkan dalam pembelajaran di masa pandmi COVID 19 seperti saat ini. Teknologi informasi sangat diperlukan dan sangat menunjang dalam melakukan proses pembelajaran.

\section{DAFTAR PUSTAKA}

Anam, Chirul. 1982. Psikologi Anak Luar Biasa. Yogyakarta : SGPLP Negeri.

Anwar Syarifudin. 1998. Kamus Bahasa Indonesia. Jakarta: PT. Gramedia.

Budiningsih C, Asri. 2005. Belajar dan Pembelajaran. Jakarta: Rineka Cipta. 
B.Uno, Hamzah. 2008. Orientasi Baru Dalam Psikologi Pembelajaran. Jakarta: PT. Bumi Aksara.

Djamarah, Syaiful Bahri. 2002. Psikologi Belajar. Jakarta: Asdi Mahasatya.

Moleong. 2009. Metode Penelitian Kualitatif. Bandung : PT Remaja Rosda Karya.

Mulyono, Abdurrahman. 2003. Pendidikan Bagi Anak Kesulitan Belajar. Jakarta: Rineka Cipta.

PHDI Pusat. 2001. Himpunan Kesatuan Tafsir Aspek-Aspek Agama Hindu I-X. Proyek Peningkatan Sarana dan Prasarana Parmajaya, 2000. Metodelogi Pengajaran Agama Hindu Denpasar: Sekolah Tinggi Agama Hindu Negeri.

Poerwadarminta. 2003. Kamus Umum Bahasa Indonesia. Jakarta : Balai Pustaka

Rachmita M. Harahap"Kata Pengantar" dalam Jamila K. A. Muhammad, Special Education for Special Children, terj. Edy Sembodo (Bandung: Hikmah, 2008).

Rama, Tri. Kamus Lengkap Bahasa Indonesia. Surabaya: Karya Agung.

Sari, Ni Nengah. 2010. Pola Pembelajaran Agama Hindu Dan Upaya Peningkatan Kualitas Pendidikan Agama di Sekolah Dasar Kecamatan Kubu Karangasem. Skripsi (tidak diterbitkan). Program studi Dharma Acarya Instsitut Hindu Dharma Negeri Denpasar.

Sutrisna, Usa. 1983. Pendidikan Anak - Anak Terbelakangan Mental. Jakarta: Debdikbud.

Suwastini, Ni Kadek. 2006. Pola Pembelajaran Pendidikan Agama Hindu di SLB/C Yayasan Kerthawiweka Denpasar. Denpasar: Institut Hindu Dharma Negeri Depasar.

Undang-Undang Dasar Negara Republik Indonesia Tahun 1945.

Undang-Undang RI No. 20 Tahun 2003. Tentang Sistem Pendidikan Nasional. Bandung : Citra Umbara.

Wiana, I Ketut. 1997. Cara Belajar Agama Hindu Yang Baik. Denpasar: Yayasan Dharma Naradha. 